\title{
JUURNAL_RU
}

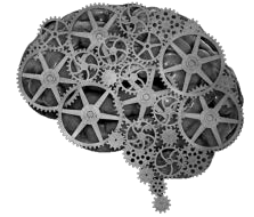

COMPANY GROUP "INTELLEKT"

\author{
Стрельчук В.Г. \\ Московский государственный университет печати имени Ивана Федорова \\ Москва, Россия
}

doi: 10.18411/lj2016-3-78

\section{Языковая игра на газетной полосе}

Языковая игра - это особый тип речевого поведения, основанный на преднамеренном, осознанном нарушении нормы. Возникающие в результате языковой игры структуры приобретают экспрессивное значение и вызывают у читателя (слушателя) определенную эмоциональную реакцию.

В языковой игре могут использоваться средства различных уровней языка - от фонетики и графики до синтаксиса.

Языковая игра обладает многими признаками, характерными для игры вообще. Как и категория игры, словесная игра создает особую, условную модель действительности. Так человечество все снова и снова творит свое выражение бытия, второй, вымышленный мир рядом с миром природы. Языковой игре так же присуща особая красота, в ней есть своеобразный ритм и гармония. Словесная игра живет по определенным правилам, которые принимают две играющие стороны: автор игры и ее реципиент, который в процессе отгадывания смыслов становится соавтором данного коммуникативного процесса.

Причем удовольствие от игры получает не только реципиент, но и сам автор, который с помощью средств языковой игры добивается эффекта предельного заострения и уточнения смысла.

«Психологической основой языковой игры является эффект обманутого ожидания: читатель (слушатель) ожидает, что в соответствии с нормами языка будет написано (произнесено) одно, а читает (слышит) совсем другое» [4]. 
Языковая игра реализует следующие функции:

- - эстетическая функция, заключающаяся в сознательном стремлении испытать самому и вызвать у реципиентов чувство прекрасного самой формой речи;

- - гностическая функция, направленная на порождение новой модели мира путем пересоздания уже существующего языкового материала;

- - гедонистическая функция, ее суть - в развлечении реципиента необычной формой речи;

- - прагматическая функция, нацеленная на привлечение внимания к оригинальной форме речи;

- - выразительная функция служит образной, и более тонкой передаче мысли;

- - изобразительная функция помогает наглядно воссоздать ситуацию говорения, а также каким-либо образом охарактеризовать человека, чьи слова передаются;

- - изредка исследователями выделяется поэтическая функция языковой игры;

- - маскировочная функция, надевающая «маску» пристойности, благоразумия и логики на любой скабрёзный, циничный или даже абсурдный текст.

Материалом для исследования послужили заголовки статей, опубликованных в газетах «Комсомольская правда» (КП), «Аргументы и факты» (АиФ), «Мир новостей» (МН). Заголовок - это обязательная структурнокомпозиционная категория любого газетного текста. Он несёт на себе важнейшую коммуникативную нагрузку. В газете подбор заголовков имеет свои особенности и сложности. Журналисты незамедлительно откликаются на текущие события. Им приходится каждодневно изобретать, придумывать всё 
новые и новые названия. Ведь для каждого номера газеты нужно подобрать несколько десятков заголовков. Заголовки призваны привлечь внимание читателей, поэтому они часто строятся на стилистическом приёме языковой игры.

Рассмотрим наиболее интересные примеры.

Во многих заголовках используется омонимическое сближение слов, при котором часть слова выделяется графически. Например:

- НАЛИЧный расчет (МК, №25205, 2010). Это интервью с известным певцом по имени Петр Налич, который прославился благодаря песни, выложенной в интернете. Об исполнителе этой песни знали только то, что это некий «петрналич» (произносится в одно слово). Потом «петрналич» как-то превратился в Петра Налича и стал знаменитым музыкантом.

- сКРАСить офисные будни - именно так назывался подзаголовок, в котором говорилось, что сочетание красного с телесными оттенками не наскучит, даже если будешь носить его каждый день.

- ПОСТУПАТельное движение - заголовок статьи о том, что нужно знать абитуриентам о поступлении в вузы накануне приемной кампании - 2015 (МК, №64 (26.776)).

- П ПОТайные знания - ещё один рекламный проект, говорящий нам о том, что принимать душ недостаточно - нужно еще нанести на чистую сухую кожу дезодорант или антиперспирант, чтобы уменьшить выделение noma.

- РАСТИтельная история - так было названо письмо читательницы журнала, в котором она написала, что жизнь заставляет её меняться и pacmu. 
- $\boldsymbol{C B}$ для двоих - в данной статье говорится о парах, чьи отношения начались в день Святого Валентина. Кроме этого аббревиатура $\boldsymbol{C B}$ ассоциируется со спальным вагоном.

Языковая игра может быть построена и на использовании в заголовках иноязычных слов.

- Их бин больной! - здесь говорится о том, что в другой стране вам могут и не поставить правильный диагноз, и медицина в этой стране возможно никогда и не слышала о вашей болезни. Здесь обыгрывается немецкое сочетание слов «их бин», которое переводится как «я есть».

В некоторых случаях используются фоносемантическое сближение русского и иностранного слова. Например, в статье рассказывается, почему один из пальцев руки называют большим. Эта статья озаглавлена Мистер Биг, здесь обыгрывается псевдоним английского комика Мистера Бина. Однако здесь с изменением согласной меняется и смысл, и сразу же становится понятно, что речь идёт о чём-то большом, так как перевод слова биг с английского языка указывает именно на это.

Очень часто источником языковой игры в заголовках становятся прецедентные тексты. Проанализированный нами материал позволяет сделать вывод, что использование прецедентных текстов распространенный способ образования заголовков.

К прецедентным текстам относятся названия общеизвестных событий, имена, строчки из художественных произведений, песен, анекдотов и т.П., которые говорящие (пишущие) воспроизводят в своей речи и которые являются символами определенных ситуаций.

В мартовском номере (№34(26362) 2015 г.) газеты «Комсомольская правда» таких примеров несколько.

- Статья под заголовком «Ну, Дисней, погоди!», которая знакомит читателей с новым проектом столичных властей российским аналогом американского города развлечений Disney в Нагатинской пойме. 
Заголовок напоминает название популярного советского и российского мультсериала «Ну, погоди!» и фразу из него «Ну, заяи, погоди!».

- «Женщина, которая не пьёт». Так называется статья о здоровом образе жизни известной исполнительницы песни «Женщина, которая поёт» Аллы Пугачевой, в связи с состоянием здоровья.

В газете «Аргументы и факты» (№13(1794) 25-31 марта 2015 г.) есть аналогичные примеры:

- «Ноль без папочки». Статья Екатерины Мирной и Дарьи Потаповой о сыне министра внутренних дел Украины Александре Авакове, купившем 6-комнатную квартиру в элитном жилом комплексе в Киеве в прошлом году, через 3 месяца после назначения его отца главой МВД. Заметим, что заголовок статьи образован от общеизвестного фразеологизма «Ноль без палочки», имеющего устойчивое значение некто, не представляющий важности, значимости, интереса без посторонней помощи.

- «Кости из будущего». Специальный репортаж Георгия Зотова из Багдада, под таким заголовком рассказывает о наличии в иракском Мосуле в наши дни двадцать лагерей боевиков «ИГ», где бывшие офицеры Саддама Хусейна тренируют будущих пилотов и танкистов. В лагерях «ИГ», запрятанных в ближневосточных пустынях, сегодня проходят обучение тысячи боевиков - потенциальных террористов. Заголовок происходит от одноименного названия «Гости из будущего», российской поп-группы, возникшей в 1996 году.

- «Время собирать мины». Статья Екатерины Сажневой в рубрике Анатомия войны. Автор пишет о специальных группах в ДНР, занимающихся разминированием. В оригинальной формулировке звучит так: «Время разбрасывать камни и время собирать камни». Цитата эта взята из Ветхого Завета (Екклесиаст, глава 3). У некоторых древних народов существовал жестокий обычай: осужденного на смерть 
преступника жестоко казнили, побивая камнями. Много человек собиралось на казни, и бросали в осужденного пленника камни, право же первых ударов предоставлялось свидетелям преступления (МК №59 (26.771) 25 марта 2015 года).

Таким образом, проанализировав заголовки выбранных газет, мы пришли к выводу, что приём использования прецедентных текстов для создания экспрессивных газетных заголовков является одним из эффективных способов привлечения читательского внимания к соответствующей информации и получает всё большее распространение в современной публицистике. Именно этот вид языковой игры чаще всего используется в заголовках газет. Следующим по распространенности приёмом языковой игры является омонимическое сближение слов.

\section{Литература:}

1. Культура русской речи: Энциклопедический словарь-справочник / Под ред. Л.Ю. Иванова и др. - М.: Флинта: Наука, 2003. - 840 с.

2. Стилистический энциклопедический словарь русского языка / Под ред. М.Н. Кожиной. - 2-е изд., испр. и доп. - М.: Флинта: Наука, 2006. - 696 с.

3. Ремчукова Е.Н. Креативный потенциал русской грамматики. Изд. 2-е, испр. и доп. М.: Книжный дом «ЛИБРОКОМ», 2011. - 224 с. 